\title{
Failure of the Croatian Higher Education Reform
}

ZORAn KURELIĆ ${ }^{1}$ AND Siniša Rodin ${ }^{\star 2}$

$\approx$ The authors analyse the reasons for Croatian higher education reform since 2003, as well as its consequences. The main proposition of the paper is that the implementation of the Bologna Process in Croatia has failed due to a fundamental misunderstanding of the goals of the process, a lack of correspondence between the cycles of higher education and the European Qualifications Framework, and a lack of international pressure, resulting from the nature of the open method of coordination. The authors present the internal market rules of the European Union and how they affect the national regulation of higher education. The paper deals with the main characteristics of the higher education reform and how it has affected the structure of higher education programmes, the comparability of degrees and qualifications, and student mobility. The authors propose an agenda for a "reform of the reform" that could bring the Croatian system of higher education back onto the European track.

Keywords: Croatia, higher education, Bologna Process, open method of coordination, professional qualifications, quality assessment, services of general interest, market access 


\section{Neuspešno reformiranje hrvaškega visokega šolstva}

ZORAN KURELIĆ IN SINIŠA RODIN*

$\propto$ Avtorja analizirata vzroke za reforme visokega šolstva na Hrvaškem po letu 2003 in posledice teh reform. Temeljna trditev članka je, da je bila implementacija bolonjskega procesa na Hrvaškem neuspešna zaradi temeljnega nerazumevanja ciljev procesa, pomanjkanja usklajenosti med cikli visokošolskega izobraževanja in evropskim ogrodjem kvalifikacij ter zaradi pomanjkanja mednarodnega pritiska, ki izhaja iz narave t. i. odprte metode koordinacije. Avtorja predstavita pravila notranjega trga $\mathrm{v}$ Evropski uniji in njihov vpliv na nacionalno urejanje visokega šolstva. Obravnavane so glavne značilnosti reform visokega šolstva ter njihov vpliv na strukturo visokošolskih študijskih programov, primerljivost stopenj in kvalifikacij ter mobilnost študentov. Avtorja predlagata agendo za »reformo reforme«, ki bi hrvaški sistem visokega šolstva lahko vrnila na evropsko pot.

Ključne besede: Hrvaška, visoko šolstvo, bolonjski proces, odprta metoda koordinacije, strokovne kvalifikacije, vrednotenje kakovosti, storitve v splošnem interesu, dostop do trga 


\section{Introduction}

It is no longer a secret that the implementation of the Bologna Process in Croatia has gone wrong. ${ }^{3}$ The higher education reform displays a significant level of anti-liberal conservative statism, which has support in parts of the academic community and in both leading parties: SDP (Social Democratic Party) and HDZ (Croatian Democratic Union). In essence, policymakers resist the Bologna Process and Europeanisation, hoping to retain the old academic and political arrangements. The system created by the reform is a bastard combining some elements of the old system with some concepts of the Bologna Process in a model that is in sync with neither the European surroundings nor Croatian society. The most obvious problems are: the destruction of the two Bologna cycles, the total lack of interdisciplinary Master's programmes (such as gender studies or European studies), bizarre degrees such as "Postgraduate Specialist", which are some sort of post-Master Master, and the frightening fact that the key degree of the reform, the Bachelor of Arts, does not even guarantee decent employability, as Croatian law recognises a Master's degree as a full qualification, not a Bachelor's degree. The fatal (politically motivated) decision to turn all pre-Bologna diploma holders into Bologna Master's degree holders by law opened a can of worms that was not fully anticipated by the policymakers responsible. What they did not know is that their moves to create a new model in a way that changes very little substantially de facto collides with the internal market of the EU and the four freedoms on which it is based. The creation of an essentially anti-liberal and anti-European model was not a conspiracy and was not brilliantly planned by cunning conservatives on the left and on the right; it was a synergy of various incompetent decisions and fears, in which universities also played their role, especially the faculties that recognised that the implementation of the Bologna Reform in Croatia could seriously damage their legal and financial independence.

The aim of the present paper is to analyse the reasons for Croatian higher education reform since 2003 , as well as its consequences. The main proposition of the paper is that the implementation of the Bologna Process in Croatia has failed due to a fundamental misunderstanding of the goals of the process, a lack of correspondence between the cycles of higher education and the European Qualifications Framework, and a lack of international pressure, resulting from the nature of the open method of coordination. In part 2, we present the

3 See the most recent interview with the President of the Republic, Mr Ivo Josipović, Jutarnji List, 14 October 2012, retrieved 4 November 2012 from: http://www.jutarnji.hr/ivo-josipovicintervju-hrvatska-ce-sigurno-uci-u-eu-1-srpnja-pa-njemacka-nas-je-podrzavala-od-samogpocetka-/1059959/. 
internal market rules of the European Union and how they affect the national regulation of higher education. Part 3 deals with the main characteristics of the higher education reform and how it has affected the structure of higher education programmes, the comparability of degrees and qualifications, and student mobility. In part 4, we propose an agenda for a "reform of the reform" that could bring the Croatian system of higher education back onto the European track.

\section{Croatian higher education, the Bologna Process and internal market rules}

The reform of the Croatian higher education model was launched in 2003 by the comprehensive reform of the Science and Higher Education Act. ${ }^{4}$ However, the most sensitive and most comprehensive part of the reform of the Croatian system of higher education coincided with the extended process of negotiations for Croatia's EU membership. Science and higher education are commonly understood as easy negotiating chapters. Chapter 25 (Science and Research) and Chapter 26 (Education and Culture) were opened and provisionally closed at the very outset of the EU membership negotiations, on 12 June and 11 December 2006, respectively.5 The Croatian Ministry of Foreign Affairs and European Integration was quick to restate that the European Union does not have a common education policy, with regulatory powers in this area being retained by Member States. ${ }^{6}$ The Chapter on Freedom of Establishment and Freedom to Provide Services was also provisionally closed on 21 December 2009. Due to the fact that certain negotiating chapters have been provisionally closed, various actors often conclude that Croatian law has been fully harmonised with EU law in a specific sector.7 The understanding that Member States enjoy wide regulatory autonomy in the higher education sector, and that the closure of relevant chapters confirms national higher education policy, will be challenged: while the Bologna Process is indeed based on an open method of coordination, EU law restricts the regulatory autonomy of its Member States in other areas of regulation, primarily through legal rules regulating the internal market and its four freedoms, that is, the free movement of goods, services, workers and capital. It will be argued that higher education, on the one hand, and freedom of establishment and freedom to provide services, on the other, have passed each other like ships in the night, which is one of the main reasons

4 Zakon o znanstvenoj djelatnosti i visokom obrazovanju, Narodne novine (Official Gazette), 123 of 31.07 .03 .

5 Retreived 30 January 2011 from http://www.mvpei.hr/ei/default.asp?ru=568\&gl=2007010900000 o2\&sid=\&jezik=1.

6 Ibid.

7 See, e.g., http://www.mingorp.hr/default.aspx?id=2051 retreived 30 January 2011. 
why Croatian higher education remains unfit to meet the requirements of the EU internal market.

In order to substantiate this claim, the first subsection will distinguish between higher education as a market service and higher education as a public good. It will also clarify how EU law affects the regulatory autonomy of Member States in the area of higher education. The second subsection will present an overview of administrative barriers that, in the sector of higher education, have the potential to restrict market freedoms. In this context, it will be demonstrated that EU internal market rules, while respecting Member States' autonomy to regulate higher education, prevent Member States from totally excluding higher education services from the market and from the application of EU internal market rules.

\section{Services of general interest in the EU internal market}

Higher education, legally speaking, can be defined either as a service that is provided on the market or as a public good that States provide to their citizens within the framework of their social function. This distinction is important because it provides a criterion for the application of EU internal market and competition rules. In the area of higher education, which is outside the scope of these rules, Member States enjoy wider regulatory autonomy and broader discretion for the implementation of their own higher education and social policy. However, in so doing, Member States must respect EU law applicable to market freedoms. In other words, Member States have the discretion to frame their respective education policy and, more generally, social policy, but must do so within the more general framework of the internal market rules and policies of the EU. The same holds for candidate countries.

The establishment and functioning of the internal market is one of the fundamental objectives of the EU. ${ }^{8}$ However, only non-economic services of general interest are exempt from the application of internal market rules. Activities that are considered economic services of general interest may be within the scope of the application of the rules applicable to free movement of goods, ${ }^{9}$ freedom to provide services, ${ }^{10}$ freedom of establishment, ${ }^{11}$ free movement of

8 Art. 3(3) TEU.

9 See case C-438/02 Criminal proceedings against Krister Hanner (2005) ECR I-4551.

10 Case C-281/o6, Hans-Dieter Jundt and Hedwig Jundt v Finanzamt Offenburg (2007) ECR I-12231.

11 Case C-153/02, Valentina Neri $v$ European School of Economics (ESE Insight World Education System Ltd) (2003) ECR I-13555. 
workers, ${ }^{12}$ and, most likely, free movement of capital, as well as being within the scope of competition rules.

Exceptions apply; a specific regime is applicable to services of general interest. However, being characterised as such does not completely exempt certain activity from the application of market rules, but only “... on the basis of principles and conditions, particularly economic and financial conditions, which enable them to fulfil their missions".13

\section{Economic and non-economic services of general interest}

Distinguishing economic from non-economic services of general interest is anything but simple. The importance of the distinction lies in the fact that economic services of general interest are considered services within the meaning of Art. 57 of the TFEU and are subject to the application of Art. 106(2) TFEU, both in the field of competition law and of the four freedoms. For example, when an economic operator, individuals included, provides services of higher education for remuneration, the situation is different. Such activities are considered economic and are within the scope of EU law. Furthermore, when an individual provides services in the form of lecturing, such activities are considered a service, since they are provided for consideration. This is the case even if the activity is performed at a public university and upon its invitation. ${ }^{14}$ By the same token, when lectures are organised in institutions that operate for profit, they are within the scope of Art. 57.15

\section{Application of internal market rules to higher education}

Higher education activities can be exempted from the application of internal market and competition rules only insofar as such activities can be entirely characterised as non-economic activities of general interest.

The basic assumption is that the choice depends on a national policy choice. However, the initial judgment of a State is subject to the scrutiny of the ECJ, and it is perfectly possible that some activities that a particular State wants

12 Case C-4/91, Annegret Bleis v Ministère de l'Education Nationale (1991) ECR I-5627. In the opinion of the ECJ, public service exception under Art 45(3) TEU is not applicable in respect to high school teachers.

13 Art. 14 TFEU. In addition, Art. 36 of the Charter of Rights of the European Union provides that " $[\mathrm{t}]$ he Union recognizes and respects access to services of general economic interest as provided for in national laws and practices, in accordance with the Treaty establishing the European Community, in order to promote the social and territorial cohesion of the Union".

14 Jundt, supra, note $6 \$ \$ 32-34$

15 Case C-109/92, Stephan Max Wirth $v$ Landeshauptstadt Hannover (1993) ECR I-6447 $\$ 17$. 
to exempt from the application of internal market rules cannot be exempted according to EU law. In the standing case law of the ECJ, some specific categories of services, such as medical or educational, cannot be automatically exempted from the application of free movement rules. ${ }^{16}$ In any case, Member States cannot exempt entire sectors of economic activities from the scope of free movement rules. ${ }^{17}$ Accordingly, some higher education activities enjoy the protection of internal market guarantees; such activities are exempted from internal market law only insofar as the internal market law could affect their basic mission, which is assessed on a case-to-case basis.

It is possible that higher education activities can be considered either as services within the meaning of Art. 57 of the TFEU, as economic services of general interest, or as non-economic services. The first case would include the provision of services on the market, the second would include, for example, a public-private partnership, while the third would cover a system of state education provided as part of a national social package.

\section{Regulatory competence in the area of higher education}

Higher education in the EU falls within the regulatory competence of Member States. According to Art. 6 of the TFEU, the EU has competence to support, coordinate or supplement national measures.

Although Member States have exclusive competence in higher education, they may not, when regulating in the field, run against the general principles of EU law, such as the principle of equal treatment, ${ }^{18}$ nor are they at license to restrict fundamental market freedoms. ${ }^{19}$ In this context, two situations have to be distinguished.

EU internal market law can preclude national law even in the non-economic sector of higher education. An example can be found in the area of the mutual recognition of qualifications; namely, MRQ is a part of internal market law that applies regardless of the nature of the activity (Rodin, 2009c). In other

16 Case 279/8o Webb (1981) ECR 3305, \$ 10; case C-158/96 Kohll (1998) ECR I-1931 \$ 20.

17 Case 131/85 Gül v Regierungspräsident Düsseldorf (1986) ECR 1573, \$17.

18 Case C-267/06 Tadao Maruko v Versorgungsanstalt der deutschen Bühnen (2008) ECR I-1757, \$59; see also C-555/o7 Seda Kücükdeveci v Swedex GmbH \& Co. KG., not yet published in ECR, \$27.

19 Starting from the early case 120/78 Rewe-Zentral AG v Bundesmonopolverwaltung für Branntwein (1979) ECR 649, \$ 8. See also C-76/05 Schwarz and Gootjes-Schwarz (2007) ECR I6849, $\$ 70$ and joined cases C-11/06 \& C-12/o6 Morgan and Bucher (2007) ECR I9161, \$24. More recently, related to higher education, see case C-73/o8, Nicolas Bressol and Others and Céline Chaverot and Others $v$ Gouvernement de la Communauté française, not yet published in ECR, $\$ 28$ : "As a preliminary point, it should be recalled that whilst European Union law does not detract from the power of the Member States as regards the organisation of their education systems and of vocational training - pursuant to Articles 165(1) and 166(1) TFEU - the fact remains that, when exercising that power, Member States must comply with European Union law, in particular the provisions on the freedom to move and reside within the territory of the Member States." 
words, Member States have only limited manoeuvring space in framing their higher education policies, despite the fact that, formally, they enjoy exclusive competence in the area of higher education (Garben, 2010).

\section{Croatian higher education law and policy}

In the light of the requirements of EU law described above, the present section will continue the analysis of Croatian higher education law and policy. In so doing, it will concentrate on their elements that encroach upon EU-related commitments. The discussion will focus on three points: the first point will expose contradictions in the Croatian system of recognition of professional qualifications, the second point will suggest that objections that the European Commission has addressed to Greece also apply to the Croatian situation, while the third point will discuss how EU citizenship and prohibition of discrimination on grounds of nationality affects Croatian higher education policy. We will demonstrate that Croatian higher education policy has created a system that is incompatible with the European qualification framework, leading to a situation where Croatian students need to study at least one year more then their European counterparts to earn the same qualification, while European degrees fail to be recognised in Croatia due to their "insufficient" length.

\section{Professional qualifications}

Differences in national systems of professional qualifications can create obstacles to freedom to provide services, freedom of establishment and free movement of workers. In an attempt to overcome such obstacles, EU law makes professional qualifications part of internal market regulation, with the general objective of contributing to market integration by measures of negative and positive integration. The main instrument of positive integration in this area is Directive 2005/36/EC, which does not seek to harmonise national systems of qualifications but instead provides for a system of mutual recognition.

The level of qualifications can be expressed in many ways. The Bologna Declaration introduced three cycles of higher education - undergraduate, graduate and postgraduate. It should be noted that the Directive, being a continuance of earlier directives applicable in the field, employs terminology that is older than the Bologna Declaration. In Art. 11, the Directive speaks about post-secondary education in the duration of a minimum of three and no more than four years to describe what has become the first Bologna cycle, and in the duration of a minimum of four years to describe the minimum for completion 
of a graduate cycle. This defines the levels and volume of qualifications as a minimum requirement for interstate mobility.

As specified in the $13^{\text {th }}$ recital of the Preamble to the Directive, national systems of higher education are grouped into different levels. The aim of such classification is only to facilitate the application of the general system of recognition, and it does not affect national educational structures or the regulatory competence of the Member States in the field. The Directive itself does not create any specific obligation regarding how Member States should frame their higher education; it only ensures that persons who have acquired a certain level of higher education can exercise their rights under the Directive.

Nevertheless, this system affects national higher education policies in an indirect way, since citizens of other Member States have access to the market under conditions that can be less strict than those required by a national system. For example, a person from another Member State who has acquired three years of post-secondary education has equal right of market access as a person who has studied for four years in the State of origin. In other words, the Directive creates a situation where three-year study programmes, and in any case four-year study programmes, lead to the acquisition of full qualifications as a condition for interstate mobility.

Firstly, possibly the most far-reaching contradictions in Croatian higher education law and policy follow from the fact that the entire higher education policy, from mid 2003 until the present day, has pursued a model according to which full qualifications for all professions is acquired after five years of postsecondary education, and such five-year qualifications are made equal to the pre-Bologna four-year cycle. This policy choice encumbers access to the labour and services market for students who have acquired qualifications at Croatian $\mathrm{HEEs}^{20}$, since, according to EU law, full qualification (and market access) is guaranteed by a minimum of three and not more than four years of education. In other words, all national requirements that oblige citizens of other Member States to meet specific criteria in order to exercise market access will be suspect from the perspective of the general system of recognition of qualifications. This holds for both public and private HEEs, since both are subject to the same national qualifications framework.

In legal terms, former four-year programmes were made equal to postBologna five-year programmes pursuant to the Science and Higher Education (Amendment) Act 2004. ${ }^{21}$ This was not only a blatant falsification of one of the

20 Higher education establishments.

21 Zakon o izmjenama i dopunama Zakona o znanstvenoj djelatnosti i visokom obrazovanju, Narodne novine (Official Gazette), 105/2004 of 28.07.04. 
objectives of the Bologna Declaration (Kurelić, 2009), but also an obstacle to the free movement of workers, services and establishment. The same policy choice was built into Art. 14 of the Law on Academic and Professional Titles and Academic Degrees. ${ }^{22}$

This coherent policy was finalised by Art. 28 of the Draft Higher Education Act, which was introduced into parliamentary procedure in mid 2011. According to $\$ 2$ thereof, undergraduate studies lead to qualifications necessary for "...work and employment in certain professional jobs of medium complexity". This is in clear contradiction to the Directive, since it restricts the freedom to provide services and free movement of workers for persons who have acquired full qualifications in three- and four-year study programmes in other Member States of the EU.

The described policy not only creates obstacles to free movement directly, but also indirectly by restricting the operation of HEEs, both public and private, since it forces them to adjust their curricula to the national qualifications framework, which itself restricts free movement.

\section{Freedom to provide services and freedom of establishment}

Can a Member State prohibit or restrict the establishment of private HEEs relying on exclusive competence in the area of higher education? Can a Member State subject private HEEs to the same legal regime as public HEEs? Can it prohibit or restrict the operation of HEEs from other Member States? To what extent is a State subject to the application of internal market rules? Examples can be found in other areas of regulation. ${ }^{23}$ Situations are comparable to the extent that higher education is understood as a service of general economic interest. State regulation must pursue a legitimate aim, e.g., a high standard of service. Furthermore, a State can restrict certain activity and reserve it for the public sector. However, it can do so only by applying criteria that exclude the discrimination of goods and services, or indeed qualifications, from other Member States.

At first glance, there are no legal obstacles in the Croatian legal system that would hinder EU HEEs, accredited in one of the Member States, in exercising freedom of establishment in Croatia. Such HEEs would be subject to Croatian law applicable to higher education only to the extent to which protection of a legitimate regulatory interest had not already been ensured in the State of

22 Zakon o akademskim i stručnim nazivima i akademskom stupnju, Narodne novine (Official Gazette), 107/2007 of 19.10.07.

23 Case C-438/02 Criminal proceedings against Krister Hanner (2005) ECR I-4551. 
their establishment. Such HEEs would be entitled to organise classes and exams and to extend qualifications, subject to compliance with the legal rules of the State in which they are established. Croatian legal rules would be applicable to them only insofar as the rules are not discriminatory, and only to extent that creates certain added value to the already existing protection under the legal rules of the State of origin. This position was expressed by the ECJ in Neri. ${ }^{24}$

The main obstacle to the establishment of HEEs was removed in 2008, when the Law on Institutions was amended. The amendments allowed thirdcountry nationals to establish HEEs in Croatia. ${ }^{25}$ Nevertheless, even after the amendment, other restrictions to freedom of establishment persist. They are embedded in the process of accreditation of HEEs established in Croatia, as well as in the accreditation of their academic programmes.

Two policy choices are particularly suspect. First, Arts. 7 and 8 of the Rules on the Contents of Accreditation Instrument ${ }^{26}$ provide that a necessary requirement for institutional accreditation is the entering of the HEE seeking accreditation into a contract with an already accredited HEE, stipulating that the two HEEs will execute the programme together. Following two years of joint performance, the already accredited HEE may issue a certificate (Art. 11) stipulating that the conditions specified in the contract have been satisfied.

In other words, market access control in higher education is entrusted to an institution that may be a direct competitor of the HEE seeking market access. The Rules do not clarify whether this is applicable to HEEs from other States, i.e., whether an accreditation-seeking HEE could enter into a contract with an HEE from, for instance, Germany or Italy. Article 2(10) of the Quality Assurance in Science and Higher Education $\mathrm{Act}^{27}$ defines the "accreditation instrument" as an "... administrative act, enacted by the Ministry, pursuant to evaluation procedure..." This leads to the conclusion that a "contract" could be entered into only with HEEs from Croatia, which makes the measure "distinctly applicable" and thus contrary to EU law. Distinctly applicable measures, generally speaking, are very difficult to justify. ${ }^{28}$ In any case, such a measure

24 Neri, supra, note 7.

25 Zakon o ustanovama. The amendment was required by the Screening Report of the European Commission for Chapter 3, of 19 July 2006. The Report found that certain institutions ("ustanove") perform commercial activity, and to that extent are subject to rules applicable to such undertakings.

26 Pravilnik o sadržaju dopusnice te uvjetima za izdavanje dopusnice za obavljanje djelatnosti visokog obrazovanja, izvođenje studijskog programa i reakreditacije visokih učilišta, Narodne novine (Official Gazette), 24/2010 of 22.02.10.

27 Zakon o osiguravanju kvalitete u znanosti i visokom obrazovanju, Narodne novine (Official Gazette), 45/2009 of 10. 04. 2009.

28 Catherine Barnard permits that certain distinctly applicable measures can still be justified. See Barnard (2010, p. 511). 
restricts market access to everyone who wants to conclude a "contract" with an HEE established outside Croatia. Even if higher education is considered a noneconomic service of general interest, such a restriction could not be justified due to its discriminatory nature (see Hanner).

The second suspect provision of the Rules is Article 2(2). This provision specifies that, in order to establish a private HEE, a bank collateral must be ensured. The purpose of the collateral is to compensate students in the case of the discontinuation of activities. The beneficiary of the collateral is the HEE with whom the accreditation-seeking HEE has entered into a contract. It is impossible to overlook the fact that a similar provision of Greek law prompted the European Commission to address a formal notice to Greece, seeking repeal of the rule. The Croatian norm does not specify the amount of the collateral, but it is clear that the amount must be agreed upon with the "already accredited HEE", that is, with a direct competitor on the market of higher education services. Furthermore, the formal notice addressed to Greece reveals the Commission's position that mandatory minimum academic requirements for professors teaching at the HEE established in other Member States, as well as their obligation to register in the registry of HE professors, is in breach of EU law. The Croatian Draft Higher Education Act also provides for minimum requirements, and is applicable without making a distinction between public and private HEEs. Similar to Greek legislation, the Croatian Draft Act does not take into account conditions that such professors have already fulfilled in another Member State. ${ }^{29}$

The obligation to register with the Registry of University Professors or, in Croatia, the Registry of Scientists, has the same restrictive potential. ${ }^{30}$ The Rules provide that all scientists appointed to scientific positions, as well as professors appointed to teaching/scientific positions, should be registered with the Registry. Even after the amendment of 1 July 2010,31 Art. 9 of the Rules provides that proof of Croatian citizenship must be attached with the request for registration.

\section{Recent Developments}

While the described legal reform was designed and implemented by the centre-right government in December 2011, following general elections, a

29 Art. 80 of the Statute of the University of Zagreb specifies that a visiting professor can be entrusted with teaching a course during two consecutive years, at the longest, subject to the permission of the Senate or a faculty council. This is a clear example of a distinctly applicable measure.

30 Pravilnik o upisniku znanstvenika, Narodne novine (Official Gazette), 72/2004 of 01.06.04, as amended, Narodne novine (Official Gazette), 82/2010 of 01.07.10.

31 Narodne novine (Official Gazette), 82/2010 of 01.07.10. 
social-democrat led coalition assumed power and formed the government. The Ministry of Science proposed the new Science and Higher Education Act in April 2012 and opened public consultations. While the draft Act introduces a number of changes, it remains restrictive in respect of all of the points mentioned above, particularly in respect of internal market rules and non-discrimination on the grounds of nationality.

Article 41 of the Draft Act creates an obstacle to the free movement of workers and prevents workers from EU Member States from applying for jobs in higher education. Restrictive provisions include an obligation to be registered with the Croatian Register of Scientists, and an obligation to be appointed to a scientific position by a State-controlled committee. Responding to these concerns, the Ministry replied that registration of foreign nationals with the Register of Scientists was made possible by recent amendments, ${ }^{32}$ and that the State Appointment Committee (matični odbor) can authorise the appointment to a scientific position of persons who have not been previously employed in Croatia. However, this is possible only if the State Appointment Committee concludes that the person concerned "meets the equivalent requirements" (zadovoljava istovjetne uvjete). ${ }^{33}$ This only enforces indirect discrimination of EU nationals, as it is necessary to go through the specific procedure before the State Appointment Committee, which checks whether the applicant meets criteria that he or she has already satisfied in his or her home State. Croatian law therefore creates double burden for such persons. In effect, university professors from the EU will be discriminated against, since their job application will have to be assessed as to the compatibility of the applicant's qualifications with Croatian requirements, as well as being subject to registration with the Croatian register. This procedure gives an automatic advantage to Croatian candidates who already work within the system of higher education, while citizens of other Member States have to confront significant administrative barriers. In order to make it crystal clear, a German or Italian professor applying for a job at a Croatian university would have to register and be subject to the assessment of Croatian appointment criteria. Meanwhile, a Croatian docent can apply for the same job without any administrative requirements.

The Draft Act also maintains the original invention introduced by the centre-right government according to which Level 6 of the European Qualifications Framework is not a fully employable qualification, while Level 7 is split into two sublevels - Level 7.1 (Master) and Level 7.2. (Postgraduate Specialist). ${ }^{34}$

32 Pravilnik o izmjenama Pravilnika o Upisniku znanstvenika, Narodne novine (Official Gazette), $72 / 04 \& 82 / 10$ ).

33 Article 12 of the Draft Act, amending Art. 33 of the original Act.

34 Article 31 of the Draft Act, amending Article 77 of the original Act. 
On the first count, Art. 71 of the Draft Act defines Bachelor studies as studies that "qualify students for graduate studies and give them the possibility of employment in certain professional jobs" (in Croatian: "Preddiplomski studij osposobljava studente za diplomski studij te im daje mogućnost zapošljavanja na određenim stručnim poslovima"). In other words, the bachelorate does not fully qualify the holder for a profession.

On the second count, the artificial distinction between Levels 7.1. and 7.2. prevents students who have acquired a Bachelor's degree level (Level 6 of the EQF) to study at Level 7.2., despite the fact that the two sublevels transfer the same level of competences. The distinction between sublevels is based on the assumption, advocated by both political options since 2003, that only a Master's level of education confers fully employable competences. Therefore, all students have to complete the Master's level in order to qualify for a profession, before they can "specialise".

According to this logic, since Bachelors are not fully qualified, they are not legally permitted to study at "postgraduate specialist" Level 7.2. Certainly, such a solution creates a system that is not internationally compatible, thus departing from one of the main goals of the Bologna Declaration. The European University Association considers such post-Master Master programmes to be "aberrant." 35

The Croatian system has already had detrimental consequences. Notably, universities are legally prohibited from admitting students holding a European Bachelor and a U.S. college degree to Level 7.2. studies; such students must take Master's degree level programmes first. However, there is no reason why they should want to take a Croatian Master's degree programme, since such programmes, in reality, transfer Bachelor-level competences necessary for entry to the first profession, and not competences belonging to Level 7 of the European Qualifications Framework.

On the side of outgoing mobility, since Croatian students need to study for five nominal years in order to obtain the first complete qualification, they will be discouraged to take a Master's degree at another university. For example, students of Economics who obtain a Bachelor's degree in Economics in Croatia and then take a one-year Master's course in, for instance, Political Marketing in Slovenia, would not be considered qualified economists in Croatia. Full qualification requires taking a consecutive Master of Economics.

The present system discloses a discrepancy between the Croatian and

35 Howard Davies, Survey of Master Degrees in Europe, European University Association (2009, p. 16): "To illustrate the diversity of provision, Trends V pointed to Master qualifications tied to the first cycle, to Master qualifications located within the third cycle, and to apparently aberrant forms such as the 'post-Master Master"' 
European systems of higher education qualifications: according to Art. 16, both sublevels 7.1. and 7.2. are linked to Level 7 of the European Qualifications Framework, and according to Art. 17 , they are linked to the $2^{\text {nd }}$ Bologna cycle. This creates a paradox according to which so-called "Postgraduate Specialist" programmes can be delivered only after the completion of the $2^{\text {nd }}$ Bologna cycle, to which they, according to law, belong. This is confirmed in the Referencing and Self-Certification Report of the Croatian Qualifications Framework to the European Qualifications Framework and to the Qualifications Framework of the European Higher Education Area. ${ }^{36}$

Indeed, EU law allows Member States to regulate their higher education systems. Furthermore, the Bologna Process is based on an open method of coordination that leaves States significant regulatory autonomy. However, the EU system of qualifications introduces a strong normative framework that Member States must comply with. In effect, mistakes made in the implementation of the Bologna Declaration can not survive the test of EU law applicable to the mutual recognition of qualifications. The two major mistakes made by Croatia are the creation of so-called postgraduate specialist degrees that belong to Level 7 EQF but are delivered within the third Bologna Cycle, and legislative prescription according to which only a Master's degree, and not Bachelor degree, confers full professional qualifications.

In the latest development, introduced by the Croatian Government on 17 October 2012, the Croatian Qualifications Framework Bill does away with Levels 7.1 and 7.2 and for the first time introduces a single Level 7 of qualifications. The Bill is currently in its first parliamentary reading. ${ }^{37}$ Not surprisingly, the Progress Report emphasised that further progress is needed in aligning Croatian legislation in the area of the mutual recognition of professional qualifications. ${ }^{38}$

36 Ministry of Science, Education and Sports Agency for Science and Higher Education, Zagreb, February 2012, p. 82. "Graduate university degrees - specialist correspond to the second cycle of QF-EHEA and sublevel 7.2 of CROQF. These degrees are awarded following the completion of accredited one to two year study programmes and students are required to earn a minimum of 60 or 120 ECTS credits, respectively." And further: "Entry into a programme may be granted to holders of degrees at CROQF sublevel 7.1. This degree is usually part of the lifelong learning educational path of employed persons who have already completed graduate university studies or specialist professional graduate study and continue their education in a certain field." http://www.sabor.hr/Default.aspx?art=50557\&sec=4604, retrieved 4 November 2012.

38 Communication from the Commission to the European Parliament and the Council on the Main Findings of the Comprehensive Monitoring Report on Croatia's state of preparedness for EU membership, Brussels, 10.10.12 $\operatorname{COM}(2012) 601$, p. 16. "In the field of right of establishment and freedom to provide services further efforts are needed, particularly for the alignment with the Services Directive and in the field of mutual recognition of professional qualifications, despite the progress achieved to date in both areas." 


\section{How to save Croatian higher education?}

\section{Inception}

The Croatian system of higher education is in jeopardy due to a series of regulatory measures introduced since 2004 that have destroyed the inherited rationality of the system without creating a coherent system that corresponds to the requirements of the European Union..$^{39}$ Instead of acting as a corrective to market failure, we have a situation in which the market is allowed to be present only in cases of State failure, i.e., in instances where the State is unable or unwilling to deliver higher education services. Moreover, the intensity of regulation has proved to be largely counterproductive, failing to allow a genuine private sector to develop while, at the same time, strangling creativity within public education by imposing strict ex ante control. In other words, the Croatian system of higher education has to be saved from arbitrary and irrational State regulation.

The inception date that led to the present state of affairs in Croatian higher education is 16 July 2004, when the Croatian Parliament adopted amendments to the Science and Higher Education Act. ${ }^{40}$ The newly introduced Art. 120 declared pre-Bologna four-year degrees ex lege equal to Bologna Master's degrees, thus initiating the synergy of horror that we witness today. This amendment created an absurd situation in which four-year Bachelor's degrees from the times of the Socialist Federal Republic of Yugoslavia are made equal to Master's degrees, while, at the same time, four-year Bachelor's degrees from European and American universities are considered bachelorates. All of the subsequent legislative interventions have only implemented this populist idea, which created a large number of ex lege Master's degree holders who lack real qualifications attributable to the Master's level. This was finally endorsed on 3 October $2007,{ }^{41}$ only a month before the general election, which can only lead to the conclusion that the government wanted to attract the loyalty of voters employed in public administration who hold such degrees. In this way, their degrees were made equal to the Master's degrees acquired by an increasing number of young people who have studied in the EU and the United States. In a paper published in 2007, Rodin argues that this is not by accident but by

39 It has been suggested by reviewers of the present paper that there is nothing for the Croatian system of higher education to be saved from. The authors disagree. We claim that the excessive role of the State has created not just an overregulated system but, indeed, a system that is incompatible with the rules of the internal market of the European Union.

40 Narodne novine (Official Gazette), 105/2004.

41 Zakon o akademskim i stručnim nazivima i akademskom stupnju (Art. 14) of 3 October 2007 (Narodne novine (Official Gazette), 107/2007). 
design, devised in order to perpetuate the pre-democratic elite (Rodin, 2007).

It is estimated that in the 2008/2009 academic year, there were 617 Croatian citizens studying in the United States alone, mainly at Master's level. Since 2006, their number has consistently been above 600.42 Writing for a Croatian newspaper, Inoslav Bešker poses the question as to whether the Croatian art of implementation of the Bologna Process is a result of incredible stupidity or whether it is sabotage. ${ }^{43}$ In our analysis, it is a result of the legal sanctioning of the interests of one powerful social group, which, confronted with the liberalisation of higher education, has successfully introduced protectionist measures and protected the status quo ante.

\section{Diagnosis}

The current Croatian higher education policy dates from July 2004. The main guiding light of the reform, as stated by the Ministry of Science, Education and Sport, was allegedly "harmonisation with European standards". In this context, the laws regulating science and higher education, the recognition of qualifications, ${ }^{44}$ quality assurance including accreditation of academic institutions and programmes, academic and professional titles ${ }^{45}$ and, ultimately, the Croatian qualifications framework, ${ }^{46}$ were adopted and amended. In 2011, a package of legislation was introduced into parliamentary procedure, regulating science, higher education and the operation of HEEs. ${ }^{47}$ Due to the change of government, these drafts were never adopted.

The main policy guidelines for the harmonisation of the Croatian higher education system with EU law were laid down in the ministries' policy document. ${ }^{8}$ Not surprisingly, the document does not even mention market freedoms, focusing instead on the participation of Croatia in EU programmes, cooperation in relevant areas of policy and the strengthening of institutional

42 Source: IRO - Institut za razvoj obrazovanja \& http://netakademija.tvz.hr/poslovni-savjetnik/ savjeti/stipendije-i-kako-ih-dobiti.html.

43 Slobodna Dalmacija, 2 November 2011.

44 Zakon o reguliranim profesijama i priznavanju inozemnih stručnih kvalifikacija, Narodne novine (Official Gazette), 124/2009 of 16.10.09.

45 Zakon o akademskim i stručnim nazivima i akademskom stupnju, Narodne novine (Official Gazette), 107/2007 of 19.10.07.

46 Zakon o osiguravanju kvalitete u znanosti i visokom obrazovanju, Narodne novine (Official Gazette), 45/2009 of 10.04.09; Pravilnik o sadržaju dopusnice te uvjetima za izdavanje dopusnice za obavljanje djelatnosti visokog obrazovanja, izvođenje studijskog programa i reakreditacije visokih učilišta, Narodne novine (Official Gazette), 24/2010 of 22.02.10.

47 Nacrt prijedloga zakona o sveučilištu, nacrt prijedloga zakona o visokom obrazovanju i nacrt prijedloga zakona o znanosti. Text available on the web page of the Ministry http://public.mzos. hr/Default.aspx?art=10240, retrieved on 30 January 2011.

48 "Izvješće o analitičkom pregledu Hrvatska, Poglavlje 26. - Obrazovanje i kultura" http://public. mzos.hr/fgs.axd?id=14470, retrieved on 30 January 2011. 
capacity. As far as legislation is concerned, none of the legal instruments discussed above refer to market freedoms. This market blindness of higher education brings the entire Croatian legislative framework into actual or potential conflict with acquis communautaire. Some of the contradictions have been identified in the regulatory practice of other Member States, and some are original Croatian inventions.

Altogether, the entire legislative framework of higher education is extremely State-oriented. This is not, in its own right, contrary to EU law. However, what is contrary is the omnipresent policy of subjecting activities that cannot be considered non-economic services of general interest to the same legal rules that are applicable to the State-controlled part of the sector. Such are the rules on institutional accreditation.

The system of professional qualifications ${ }^{49}$ represents a problem in itself. The problem is twofold: on the one hand, it is discriminatory for holders of Croatian qualifications since they can acquire full qualification only after five years of post-secondary education, instead of three or four years, as envisaged by the Directive 2005/36/EC; on the other hand, since it is contrary to the Directive, the same rules cannot be applied to students from other Member States, who enjoy market access after three and four years, respectively.

These policy choices were entertained by the three governments (two centre-right and the present centre-left) in power since 2003. The latest wave of reform maintains and entrenches the three key mistakes that were seeded already in 2003: a restrictive approach to market freedoms and inherent discrimination on the grounds of nationality, an incomprehensible and internationally incompatible system of qualifications where a Master-after-Master degree has become the main form of education within the third Bologna cycle, and comprehensive governmental control of student admission, academic appointment and initial accreditation requirements applicable not only to State universities but, indeed, to private universities as well. Against this backdrop, the present authors propose ten policy guidelines.

\section{The Cure?}

The following policy recommendations tackle the major causes of the present disease that plagues Croatian higher education. Our proposal takes into account the lack of international compatibility with Croatian degrees and qualifications, the excessive encroachment of the State into the autonomy of higher

49 Legislation on the Croatian Qualifications Framework has been drafted and awaits parliamentary approval. 
education, State control of market access and quality assessment. In addition to the these areas, the proposal attempts to strike a balance between a meaningful openness to the private sector and an adequate social framework that should allow wide access to public higher education. ${ }^{50}$

1. A Bachelor's degree must lead to a complete and fully employable qualification after three or four years of post-secondary education.

2. One-year Master's degrees that can be made part of graduate (doctoral) schools should lead to qualifications of Level 7 of the European Qualifications Framework, without the artificial differentiation of Levels 7.1 and 7.2.

3. A voucher system guaranteeing four years of free at point of delivery study for students, and combined public/private financing of Master's degrees. Vouchers should be redeemable by both state and private universities.

4. Public financing of three-year doctoral research programmes for full-time doctoral students.

5. Recognition of accreditations issued by European accreditation agencies that are members of ENQA (de-monopolisation of the Croatian Accreditation Agency).

6. Introduction of the possibility of accrediting graduate universities (i.e., universities that offer graduate degrees only), and of the possibility for science institutes to accredit and run graduate degree programmes.

7. Removal of barriers to the operation in Croatia of higher education establishments established in other States, and removal of barriers to the employment of university professors and other staff. State Appointment Committees should be abolished or restricted to ex post quality assessment.

8. Formal differentiation between university and professional degree programmes should be abolished and replaced by a system of professional qualifications based on learning outcomes.

9. Meaningful annual quality assessments of higher education establishments and publication of rankings.

10. Tax benefits for studying and investment in science and higher education.

These ten policy guidelines address a Croatian policy deficit that has persisted in the area of higher education since 2003. In spite of radical State

50 While our proposal has been ignored by the government, it has caused some debate and reaction amongst academia. Some of the discussions are accessible on the pages of Banka Magazine. http:// www.bankamagazine.hr/Naslovnica/Komentariianalize/tabid/138/View/Details/ItemID/73536/ ttl/Deset-teza-za-reformu-visokog-obrazovanja/Default.aspx retrieved on 9 June 2012. 
intervention, today, after eight years, one can say that Croatia is worse off than before the commencement of the reforms. The central claim that we have tried to demonstrate in the present paper is that the reason for its failure is not the Bologna Declaration, but rather its Croatian travesty.

The existing system has created a perverse situation in which the number of Master's students is larger than the number of Bachelors. This has to change. Admission to the Master's level must be selective, and in order to be selective, a Bachelor's degree must lead to a full and employable qualification that is relevant for the labour market. Four-year Bachelor's degrees are part of the Croatian and European tradition and, with some exceptions, are implemented across the EU and the US.

This brings us to the social dimension of the system we are proposing. A system that cannot qualify students for the labour market in four years is not only inefficient but also socially unjust. Croatian and European families are increasingly unable to bear the economic burden of education. Even where tuition is not charged, high living expenses have to be met. An additional economic burden is created by the delayed entry of students into the labour market. Our policy proposal creates a win-win situation: students and their parents win due to the shortened period of studying, while universities win due to the fact that new sources of financing are becoming available at the Master's level, i.e., public national and European funding combined with tuition. Indeed, one part of the students will have to bear their own costs for education at the Master's level, but the first employable qualification will be conferred by a Bachelor's and not by a Master's degree, as is the case now. Finally, the proposed system will decrease public spending, as only four-year degrees leading to the first employable qualification will be financed from the public purse, and not extensive multi-annual studies, as is the case now.

The proposal also takes in account EU law applicable to the mutual recognition of qualifications. The present system, according to which the first employable qualification is acquired at the Master's level, makes any selection of Master's students impossible. Under the present system, each and every student, regardless of his or her grade point average, must study for five years until having acquired a Master's degree. This entails the requirement of a Master's thesis for a large number of students. Some faculties already have more Master's than Bachelor students. Under such circumstances, it is increasingly difficult to maintain the quality of teaching at Master's level, and the large number of Master's research papers generates unethical behaviour, including plagiarism. In other words, a Master's thesis is degraded to the level of a pre-Bologna graduation paper, which makes it incomparable with European Master's degrees. 
The problematic quality of education at Master's level and the lack of meaningful selection lead to competences that are inadequate for doctoral research. Master's students are not qualified to pursue doctoral research, and the missing competences have to be compensated for during doctoral studies. This, in turn, leads to longer periods of study at doctoral level.

Once Croatia joins the EU in 2013, higher education will remain in its competence. As far as the EU is concerned, the Croatian system of higher education can continue to exist in its present dysfunctional form. However, if nothing changes, as appears to be the case, Croatian students will not acquire competences relevant to the European labour market. Croatian students will increasingly seek education and employment in other Member States and Croatian higher education will become increasingly irrelevant.

\section{Post Scriptum}

On 6 October 2012, the Croatian government withdrew the Science and Higher Education Bill from parliamentary procedure.

\section{Reference}

Barnard, C. (2010). The Substantive Law of the EU, $3^{\text {rd }}$ ed. Oxford: OUP.

Davies, H. (2009). Survey of Master Degrees in Europe. European University Association.

Garben, S. (2010). The Bologna process and the Lisbon Strategy: Commercialisation through the

Back Door. Croatian Yearbook of European Law \& Policy, 6, 167-208.

Ivošević V., \& Miklavić, K. (2009). Financing Higher Education: Comparative analysis. In M.

Vuksanović (Ed.), Financing Higher Education in SEE: Albania, Croatia, Montenegro, Serbia, Slovenia

(pp. 64-110). Belgrade: Centre for Education Policy.

Kurelić, Z. (2003). Postoji li “naša” i “vaša” znanost? Politička misao, 4o(4), 163-168.

Kurelić, Z. (2009). How Not to Defend Your Tradition of Higher Education. Politička misao, 46(5), 9-20.

Kurelić, Z. (2011). Antibolonja i društvo znanja. In V. Afrić, D. Polšek, L. Bakić-Tomić, \& K. Žažar (eds.), Društvene pretpostavke društva znanja. Zagreb: FF Press.

Kurelić, Z. (2012). One World One Fight. Anali Hrvatskog politološkog društva, 8(1), 37-48.

Rodin, S. (2007). Identity and Divergence of Discourses in Croatia and Europe. Croatian Yearbook of European Law and Policy, 3(8), 229-240.

Rodin, S. (2007). Usklađivanje hrvatskog kvalifikacijskog okvira s Europskim kvalifikacijskim okvirom. Informator, 55(1-3), 5591-5592.

Rodin, S. (2009a). Direktiva Europske unije 123/2006 o uslugama - doseg i opravdanja. In Zbornik Pravnog fakulteta u Zagrebu (pp. 33-61). Zagreb: Pravni fakultet. 
Rodin, S. (2009b). Scope of the Services Directive 2006/123/EC. In R. Knez (Ed.), Internal Market For Services (9-24). Maribor: Pravna fakulteta Univerze v Mariboru.

Rodin, S. (2009c). Higher Education Reform in Search of Bologna. Politička misao, 46(5), 21-38 Rodin, S. (2010). European Benchmarking and National Interpretation - Is the Bologna Process a "magyaron narancs"? In N Bodiroga-Vukobrat, G. Sander, \& S. Barić (Eds.), Die Offene Methode der Koordinierung in der Europäischen Union (pp. 79-10o). Hamburg: Verlag Dr. Kovač.

Wyatt, D., \& Dashwood, A. (2006). European Union Law, ${ }^{\text {th }}$ edition. Hart Publishing.

\section{Sources}

\section{Case law of the ECJ}

2/74 Reyners $v$ Belgium (1974) ECR 631

120/78 Rewe-Zentral AG v Bundesmonopolverwaltung für Branntwein (1979) ECR 649 279/80 Webb (1981) ECR 3305

131/85 Gülv Regierungspräsident Düsseldorf (1986) ECR 1573

263/86 Belgian State v René Humbel and Marie-Thérèse Edel (1988) ECR 5365

42/87 Commission v Belgium (1988) ECR 5445

C-4/91 Annegret Bleis v Ministère de l'Education Nationale (1991) ECR I-5627

C-109/92 Stephan Max Wirth v Landeshauptstadt Hannover (1993) ECR I-6447

C-55/94 Reinhard Gebhard v Consiglio dell'Ordine degli Avvocati e Procuratori di Milano (1995) ECR

I- 4165

C-96/94 Centro Servizi Spediporto (1995) ECR I-2883

C-157/94 Commission v. Netherlands (1997) ECR I-5699

C-158/96 Kohll (1998) ECR I-1931

C-266/96 Corsica Ferries France SA v Gruppo Antichi Ormeggiatori del porto di Genova Coop. arl,

Gruppo Ormeggiatori del Golfo di La Spezia Coop. arl and Ministero dei Trasporti e della Navigazione (1998) ECR I-3949

C-145/99 Commission v Italy (2002) ECR I-2235

C-280/oo Altmark Trans GmbH and Regierungspräsidium Magdeburg v Nahverkehrsgesellschaft Altmark GmbH, and Oberbundesanwalt beim Bundesverwaltungsgericht (2003) ECR I-7747

C-153/o2 Valentina Neri v European School of Economics (ESE Insight World Education System Ltd) (2003) ECR I-13555

C-438/o2 Criminal proceedings against Krister Hanner (2005) ECR I-4551

C-76/05 Schwarz and Gootjes-Schwarz (2007) ECR I6849

C-274/05 Commission of the European Communities v Hellenic Republic (2008) ECR I-7969

C-11/o6 \& C-12/o6 Morgan and Bucher (2007) ECR I9161

C-267/o6 Tadao Maruko v Versorgungsanstalt der deutschen Bühnen (2008) ECR I-1757

C-281/o6 Hans-Dieter Jundt and Hedwig Jundt v Finanzamt Offenburg (2007) ECR I-12231 
C-39/o7 Commission of the European Communities v Kingdom of Spain (2008) ECR I-3435

C-555/o7 Seda Kücükdeveci v Swedex GmbH \& Co. KG., not yet published

C-570/o7 \& C-571/o7, José Manuel Blanco Pérez and María del Pilar Chao Gómez v Consejería de

Salud y Servicios Sanitarios and Principado de Asturias, not yet published

C-73/o8 Nicolas Bressol and Others and Céline Chaverot and Others v Gouvernement de la

Communauté française, not yet published

C-515/o8 Criminal proceedings against Vitor Manuel dos Santos Palhota and Others, not yet published

Mišljenje n.o. Trstenjak u predmetu C-16o/o8 Commission v. Germany, not yet published

\section{Documents}

Directive 2005/36/EC of the European Parliament and of the Council of 7 September 2005 on the recognition of professional qualifications OJ L 255, 30.9.05.

Directive 123/2006/EC of the European Parliament and of the Council, on Services in the Internal

Market O. J. L 376/36, 27.12.06.

European Parliament Resolution of 13 January 2004 on the Green Paper on services of general interest [A5-0484/2003].

Green Paper on Services of General Interest Brussels, 21.05.03 COM (2003) 270 final.

Higher Education Governance in Europe, European Commission - Eurydice, Brussels 2008.

Petition $0477 / 2007$ by Catherina Groeneveld (Irish), on a ban on private instruction at home in

Germany, of 30 January 2009.

Pravilnik o upisniku znanstvenika, Narodne novine (Official Gazette), 72/2004 of 01.06.2004. S izmjenama, Narodne novine (Official Gazette), 82/2010 of 01.07.10.

Pravilnik o sadržaju dopusnice te uvjetima za izdavanje dopusnice za obavljanje djelatnosti visokog obrazovanja, izvođenje studijskog programa i reakreditacije visokih učilišta, Narodne novine (Official Gazette), 24/2010 of 22.02.10.

Zakon o reguliranim profesijama i priznavanju inozemnih stručnih kvalifikacija, Narodne novine (Official Gazette), 124/2009 of 16.10.09.

Zakon o akademskim i stručnim nazivima i akademskom stupnju, Narodne novine (Official Gazette), $107 / 2007$ of 19.10 .07 .

Zakon o osiguravanju kvalitete u znanosti i visokom obrazovanju, Narodne novine (Official Gazette), 45/2009 of 10.04.09. 


\section{Biographical note}

Zoran Kurelić is a professor of political theory at the Faculty of Political Science, University of Zagreb. He is the chair of the department for political and social theory and the director of the doctoral programme of the Faculty. Kurelic graduated at the University of Zagreb, he got his Masters degree at the London School of Economics, and his Ph.D. at the New Shool for Social Research in New York. He teaches a few courses on undergraduate, graduate and postgraduate level (Epistemology and Politics, Contemporary Political Theory and Liberalism and Nationalism). Lately he has been interested in reinterpretations of Hannah Arendt's philosophy and the limits of social liberalism.

SINIša Rodin, Prof., earned his Ph.D. degree from University of Zagreb Faculty of Law, Croatia in 1995, and his LL.M. degree from the University of Michigan Law School in Ann Arbor, Michigan in 1992. He specialized European Law at the European University Institute in Florence, and at Max-Planck Institut für ausländisches öeffentliches Recht und Völkerrecht in Heidelberg. In 2001/2002 he was a Fulbright fellow and Visiting Scholar at Harvard Law School and in 2012 Marc and Beth Goldberg distinguished professor at Cornell University Law School. Prof. Rodin holds an ad personam Jean Monnet Chair at University of Zagreb, Faculty of Law. 